\title{
Formulasi food bars berbahan baku koropedang putih (Canavalia ensiformis) autoclaving - cooling
}

\author{
Formulation of food bars made from white jack bean (Canavalia ensiformis) \\ autoclaving - cooling
}

\author{
Atina Rahmawati ${ }^{1 *}$, Wirawan ${ }^{1)}$ \\ ${ }^{1}$ Program Studi Teknologi Industri Pertanian, Fakultas Pertanian, \\ Universitas Tribhuwana Tunggadewi \\ *Email korespondensi : atina21@ yahoo.com
}

Informasi Artikel:

Dikirim: 14/11/2020; disetujui: 20/07/2021; diterbitkan: 20/09/2021

\begin{abstract}
White jackbean is type of bean that grows in tropical and subtropical areas. White jackbean has large protein and complex carbohydrate content. The autoclaving - cooling process can be used tochange starch intoresistant starch in the white jackbe an flour through gelatinization and retrogradation processes. White jackbean flour treated with autoclaving - cooling process can be used as a raw material for the formulation of food bars. Currently food bars have been in great demand along with the needs toconsume healthy and nutritious ready-to-eat food. This study aims todetermine the appropriate formulation of white jack bean flour treated with autoclaving - cooling process toproduce food bars with the best physical, chemical and organoleptic properties.The results showed that the best formulation is the formulation of white jackbean flour: wheat flour $=60: 40$ with $48.81 \%$ carbohydrate content, $14.87 \%$ protein content, $16.57 \%$ fat content, $17.07 \%$ moisture content, $2.68 \%$ ash content, 2269.3 gf breaking strength, $6.43 \mathrm{~N}$ texture, 79.59 color $(L), 15.71$ color $(a), 17.21$ color $(b), 4.02$ color organoleptic, 3.88 flavor organoleptic, 3.83 aroma organoleptic, 3.83 texture organoleptic. and 11,38\% resistant starch content.
\end{abstract}

Keywords: Food bars, white jackbean flour, autoclaving - cooling

\begin{abstract}
ABSTRAK
Koropedang putih merupakan salah satu jenis kacang koroyang banyak tumbuh di daerah tropis dan subtropis. Koropedang putih memiliki kandungan protein dan karbohidrat kompleks yang cukup besar. Proses autoclaving - cooling dapat dimanfaatkan untuk mengubah pati menjadi pati resisten pada tepung koropedang putih melalui proses gelatinisasi dan retrogradasi. Tepung koropedang putih autoclaving cooling dapat dimanfaatkan sebagai bahan baku formulasi pembuatan food bars. Saat ini food bars telah banyak diminati sejalan dengan perkembangan jaman yang menuntut manusia mengkonsumsi makanan siap saji yang sehat dan bergizi. Penelitian ini bertujuan untuk menentukan formulasi penambahan tepung koropedang putih autoclaving - cooling yang tepat untuk menghasilkan food bars dengan sifat fisik, kimia dan organoleptik terbaik. Hasil penelitian menunjukkan bahwa formulasi penambahan tepung koropedang putih autoclaving-cooling yang tepat untuk menghasilkan food bars dengan sifat fisik, kimia dan organoleptik terbaik adalah pada perbandingan tepung koropedang putih autoclaving - cooling : tepung terigu $=60: 40$. Formulasi ini memiliki karakteristik kadar karbohidrat 48,81\%, kadar protein 14,87\%, kadar lemak 16,57\%,
\end{abstract}


kadar air 17,07\%, kadar abu 2,68\%, daya patah 2269,3 gf, tekstur 6,43 N, warna (L) 79,59, warna (a) 15,71, warna (b) 17,21, organoleptik warna 4,02, organoleptik rasa 3,88 , organoleptik aroma 3,83, organoleptik tekstur 3,83, dan kadar pati resisten $11,38 \%$.

Kata kunci: Food bars, tepung koropedang putih autoclaving - cooling

\section{PENDAHULUAN}

Koropedang putih merupakan salah satu jenis kacang koroyang banyak tumbuh di daerah tropis dan subtropis (Subagio, 2005). Di Indonesia koropedang putih telah dibudidayakan di Bengkulu, Lampung, Jawa, Bali dan Nusa Tenggara Barat. Produksi koropedang putih rata-rata 7 ton/ha (Balitkabi, 2012). Koropedang putih memiliki kandungan protein dan karbohidrat kompleks yang cukup besar. Karbohidrat kompleks merupakan istilah untuk polimer karbohidrat yang tersusun atas 3 atau lebih gula yang terhubung membentuk suatu rantai (Foster et al., 2002). Karbohidrat kompleks terdiri dari pati, oligosakarida, polisakarida non pati, dan termasuk juga pati resisten (Topping, 2007).

Proses autoclaving-cooling dapat digunakan untuk mengubah pati menjadi pati resisten melalui proses gelatinisasi dan retrogradasi (Sajilata et al., 2005). Proses gelatinisasi terjadi saat autoclaving, yaitu granula pati mengembang, kemudian mengalami kerusakan dan terjadi pelarutan amilosa dan amilopektin ke dalam air, dan pada akhirnya membentuk pasta. Pada saat pendinginan terjadi proses retrogradasi, yaitu kecenderungan rantai pati untuk berikatan kembali, dan pada kondisi tertentu terbentuk struktur kristalin sehingga terbentuk pati resisten yang sulit dicerna (Estiasih, 2006). Kandungan pati resisten karbohidrat kompleks koropedang putih meningkat dari $14,12 \%$ menjadi $16,68 \%$ dengan perlakuan satu siklus autoclaving - cooling (Rahmawati et al., 2018 ${ }^{\mathrm{a}}$ ).

Pati resisten berdasarkan definisi terbaru dari AACC (AACC, 2000 dalam Nugent, 2005) telah masuk dalam kategori serat pangan, karena sangat tahan terhadap enzim pencernaan, dan dapat difermentasi sebagaimana serat larut (Sajilata et al.,
2005). Pati resisten memiliki kemampuan untuk menurunkan kadar kolesterol (Rahmawati et al., 2018b).

Tepung koropedang putih autoclaving - cooling dapat dimanfaatkan sebagai bahan baku formulasi pembuatan food bars. Saat ini food bars telah banyak diminati sejalan dengan perkembangan jaman yang menuntut manusia mengkonsumsi makanan siap saji yang sehat dan bergizi. Penelitian ini bertujuan untuk menentukan proporsi tepung koropedang putih autoclaving - cooling : tepung terigu yang tepat untuk menghasilkan food bars dengan sifat kimia, fisik, dan organoleptik terbaik.

\section{METODE}

\section{Bahan}

Bahan baku yang digunakan dalam penelitian ini adalah koropedang putih dengan umur panen 90 hari dari kabupaten Temanggung, Jawa Tengah. Bahan penunjang yang digunakan dalam penelitian ini antara lain aquades, tepung terigu, gula, garam, margarin, susu bubuk, telur dan vanili.

\section{Alat}

Alat-alat yang digunakan dalam penelitian ini antara lain: tabung autoclave, refrigerator, timbangan, glassware, cabinet dryer, ayakan, oven, texture analyzer.

\section{Metode/pelaksanaan}

\section{Pembuatan tepung koropedang putih}

Pembuatan tepung koropedang putih dilakukan menurut metode Rahmawati et al. $\left(2018^{\mathrm{a}}\right)$ dengan modifikasi. Biji koropedang putih direndam dalam air (koropedang putih : air $=1: 3 \mathrm{~b} / \mathrm{v}$ ) selama $12 \mathrm{jam}$, setelah itu dilakukan pengupasan kulit secara manual. Perendaman berfungsi untuk memudahkan pengupasan kulit biji koropedang putih. Selanjutnya dilakukan perendaman lagi selama 3 × 12 jam dengan penggantian air setiap 12 jam. Perendaman ini 
berfungsi untuk mengurangi $\mathrm{HCN}$ dari koropedang putih. Setelah perendaman 3 x 12 jam kemudian dicuci, ditiriskan dan dihancurkan dengan menggunakan blender. Selanjutnya hancuran koropedang putih dikeringkan pada cabinet dryer suhu $55^{\circ} \mathrm{C}$ selama 16 jam, digiling dengan blender dan kemudian diayak dengan saringan 60 mesh. Tepung yang lolos ayakan selanjutnya dianalisis. Tepung koropedang putih dianalisis kadar air, protein, lemak, abu (Anonim, 1996) dan kadar pati resisten (Englysh et al., 1992).

\section{Pembuatan tepung koropedang putih autoclaving - cooling}

Siklus autoclaving - cooling diterapkan pada tepung koropedang putih dengan tujuan untuk meningkatkan kadar pati resistennya. Proses autoclaving - cooling dilakukan sebagaimana metode yang dilakukan oleh Rahmawati et al. $\left(2018^{\mathrm{a}}\right)$ dengan modifikasi. Sebagai perlakuan awal, tepung koropedang putih dicampur dengan air dengan perbandingan tepung : air $=1: 4(\mathrm{~b} / \mathrm{v})$ hingga membentuk pasta. Pasta tersebut kemudian dimasak bertekanan dalam autoclave pada suhu $121^{\circ} \mathrm{C}$ selama 15 menit, diturunkan suhunya pada suhu kamar dan selanjutnya disimpan (cooling) pada suhu $4^{\circ} \mathrm{C}$ selama 24 jam, kemudian hasilnya dikeringkan dengan cabinet dryer bersuhu $55^{\circ} \mathrm{C}$, digiling dan diayak dengan ayakan 60 mesh. Tepung koropedang putih autoclaving - cooling selanjutnya dianalisis kadar air, protein, lemak dan abu (Anonim, 1996) dan kadar pati resisten.

\section{Pembuatan food bars}

Tepung koropedang putih autoclaving - cooling : tepung terigu dengan perbandingan $90: 10,80: 20,70: 30,60$ : 40, dan $50: 50$ dicampur dengan gula halus $15 \%$, garam $2 \%$, vanili $2 \%$, margarin $20 \%$, telur 2 butir, susu bubuk $5 \%$, aquades $2 \%$, dan CMC 2\%. Cetak adonan dengan bentuk memanjang, Selanjutnya dilakukan pemanggangan dengan oven pemanggangan bersuhu $160^{\circ} \mathrm{C}$ selama 40 menit hingga menjadi produk food bars, dilakukan analisis kadar proksimat (air, abu, protein, lemak, karbohidrat by difference), tekstur, daya patah, warna (L, a, b), organoleptik (rasa, warna, aroma, tekstur), dan kadar pati resisten (pada food bars perlakuan terbaik).

\section{Rancangan penelitian}

Rancangan penelitian yang digunakan pada penelitian ini adalah Rancangan Acak Lengkap (RAL) dengan 1 faktor yaitu proporsi tepung koropedang putih autoclaving - cooling : tepung terigu dengan 3 kali ulangan. Perlakuan pada penelitian adalah proporsi tepung koropedang putih autoclaving - cooling : tepung terigu dengan perbandingan $90: 10$, $80: 20,70: 30,60: 40$, dan $50: 50$.

Analisa dilakukan pada tepung koropedang putih adalah kadar pati resisten, kadar proksimat (kadar air, kadar abu, kadar protein, kadar lemak, kadar karbohidrat by difference). Analisa pada tepung koropedang putih autoclaving - cooling meliputi kadar pati resisten, kadar proksimat (kadar air, kadar abu, kadar protein, kadar lemak, kadar karbohidrat by difference). Analisa pada food bars meliputi kadar pati resisten, kadar proksimat (kadar air, kadar abu, kadar protein, kadar lemak, kadar karbohidrat by difference), analisa tekstur, analisa daya patah, analisa warna, dan analisa organoleptik (rasa, warna, aroma, tekstur).Selanjutnya data dianalisa dengan menggunakan ANOVA dan apabila berbeda nyata maka dilanjutkan dengan uji Tukey test.

\section{Analisis kandungan proksimat}

Analisis kandungan proksimat dilakukan menurut prosedur AOAC (2004).

\section{Analisis pati resisten}

Analisis pati resisten ditentukan dengan menggunakan metode Englyst et al. (1992). Sampel sebanyak $1 \mathrm{~g}$ ditempatkan dalam tabung sentrifus. Sampel dicuci menggunakan $8 \mathrm{ml}$ etanol $80 \%$, selanjutnya disentrifus pada kecepatan $554 \mathrm{x}$ g selama 10 menit dan diulang dua kali. Residu pati ditambahkan $20 \mathrm{ml}$ buffer sodium asetat $(0,1 \mathrm{M}$ pH 5,2), selanjutnya dididihkan dalam penangas air selama 30 menit.

Sampel didinginkan dan ditambah $5 \mathrm{ml}$ larutan enzim yang mengandung ekstrak pankreatin dan amiloglukosidase. Larutan enzim disiapkan dengan cara 
mensuspensikan 3,0 g pankreatin (Sigma, Cat. No. P7545) ke dalam $20 \mathrm{ml}$ air deionisasi, distirer selama 10 menit pada suhu ruang dan disentrifus dengan kecepatan $1500 \times \mathrm{g}, 4^{\circ} \mathrm{C}$ selama 10 menit.

Sebanyak 13,5 ml supernatan pankreatin ditambah $0,25 \quad \mathrm{ml}$ amiloglukosidase $210 \mathrm{U}$ (Sigma Cat. No. A7095) dan 1,25 $\mathrm{ml}$ air deionisasi. Selanjutnya, sampel diinkubasi dalam shaker water bath pada suhu $37 \square \mathrm{C}$ selama 20 menit untuk menentukan kadar RDS (pati cepat cerna) dan 120 menit untuk SDS. RDS dinyatakan sebagai total pati yang dicerna selama 20 menit pertama, dan SDS dinyatakan sebagai total pati yang dicerna antara 20 dan 120 menit. Jumlah gula hasil hidrolisis pati diukur dengan menggunakan metode DNS.

$\%$ Kadar $R S=100 \%-R D S-S D S$

\section{Analisis daya patah}

Analisis daya patah menggunakan prosedur Choy et al., (2010). Texture Analyzer yang sudah dihubungkan dengan komputer dinyalakan dan diatur Test type: Compression, Trigger 4 point: 50 g, Target value: $2 \mathrm{~mm}$, No. cycles: 1, Test speed: 1 $\mathrm{mm} / \mathrm{s}$, Probe type: TA 18, Hold time: $0 \mathrm{~s}$, Recovery time: 0 s. Sampel flakes diukur ketebalannya dan diameternya kemudian diletakkan pada meja sampel. Alat dijalankan, probe akan bergerak menyentuh sampel hingga fracture, kemudian probe berhenti bergerak dan kembali ke posisi semula.

\section{Analisis tekstur}

Analisis tekstur dilakukan menurut metode TA-HD plus (Engelen, 2018). Probe yang digunakan berbentuk silinder dengan diameter $35 \mathrm{~mm}$. Pengaturan TAXT-2 yang digunakan adalah sebagai berikut : pre test speed $2,0 \mathrm{~mm} / \mathrm{s}$, test speed $0,1 \mathrm{~mm} / \mathrm{s}$, rupture test distance 50\%, mode TPA (Texture Profile Analysis). Sampel keripik daun kelor JASc, Vol 2 No1, Mei 201812 diletakkan di atas landasan lalu ditekan oleh probe. Sampel ditekan oleh probe sejauh 50\% dari ukuran asal dengan kecepatan $0.1 \mathrm{~mm} / \mathrm{s}$, kemudian berhenti dengan jeda waktu 5 s, probe melakukan penekanan kedua sejauh $50 \%$ ukuran asal dengan kecepatan 0.1 $\mathrm{mm} / \mathrm{s}$. Gaya yang dibutuhkan untuk kompresi diukur. Berdasarkan kurva didapatkan nilai yang berupa kekerasan. Nilai kekerasan ditunjukkan dengan absolute (+) peak yaitu gaya maksimal, dengan satuan parameter ini adalah gram force (gf).

Analisis warna ( $L, a, b)$

Pengujian warna dilakukan menggunakan Colour Reader Minolta, kemudian diukur menggunakan sistem Hunter (Hunter, 1952) dengan menentukan nilai $\mathrm{L}, \mathrm{a}, \mathrm{b}$

\section{Analisis organoleptik}

Uji organoleptik (Kartika et al., 1988) yang dilakukan adalah warna, aroma, daya patah, kerenyahan, rasa, dan mouthfeel. Uji kesukaan menggunakan metode scoring dengan skala 1 (sangat tidak suka) - 7 (sangat suka). Pengujian diikuti oleh 91 orang panelis tidak terlatih.

\section{Analisis data}

Data yang didapat akan dianalisis dengan Analysis of Variance (ANOVA), apabila menunjukan beda nyata maka analisis data dilanjutkan dengan uji Beda Nyata Terkecil (BNT) dengan taraf 5\%, dan apabila hasil analisis menunjukan beda sangat nyata maka akan dilanjutkan dengan menggunakan BNT dengan taraf $1 \%$.

\section{Analisis perlakuan terbaik}

Penentuan perlakuan terbaik menggunakan indeks efektifitas yang mengacu kepada De Garmo (2004) dengan langkah sebagai berikut : 1. Penentuan Bobot Parameter (BP) dan Bobot Normal (BN). Parameter pada nomor urut satu diberi bobot nilai 1, kemudian parameter berikutnya diberi bobot nilai 0,9 dan seterusnya dengan pengurangan nilai 0,1 . Bobot Normal $(\mathrm{BN})$ ditentukan dengan cara nilai Bobot Parameter (BP) dari masing-masing parameter dibagi dengan total nilai bobot parameter (bobot nilai mulai parameter pertama sampai terkahir dijumlahkan) sehingga diperoleh bobot normal dari masing-masing parameter. 2. Penentuan 
Nilai Terjelek dan Terbaik. 3. Penentuan Nilai Efektifitas (NE) dan Nilai Hasil (NH). Nilai Efektifitas menggunakan rumus sebagai berikut :

Nilai Efektifitas $(\mathrm{NE})=$
$\frac{\text { Nilai pengamatan-nilai terjelek }}{\text { Nilai terbaik-nilai terjelek }}$

Sedangkan NH ditentukan dengan menggunakan rumus sebagai berikut :

Nilai Hasil $(\mathrm{NH})=\mathrm{BN} \times \mathrm{NE}$

Berdasarkan perhitungan menggunakan rumus diatas maka perlakuan dengan angka tertinggi adalah perlakuan terbaik.

\section{HASIL DAN PEMBAHASAN}

Komposisi kimia tepung koropedang putih dan tepung koropedang putih autoclaving-cooling

Perbandingan komposisi kimia tepung koropedang putih dan tepung koropedang putih autoclaving - cooling ditunjukkan pada Tabel 1. Perbedaan komposisi kimia antara keduanya disebabkan karena adanya proses autoclaving - cooling pada tepung koropedang putih.

Tabel 1. Komposisi kimia tepung koropedang putih dan tepung koropedang putih autoclaving-cooling

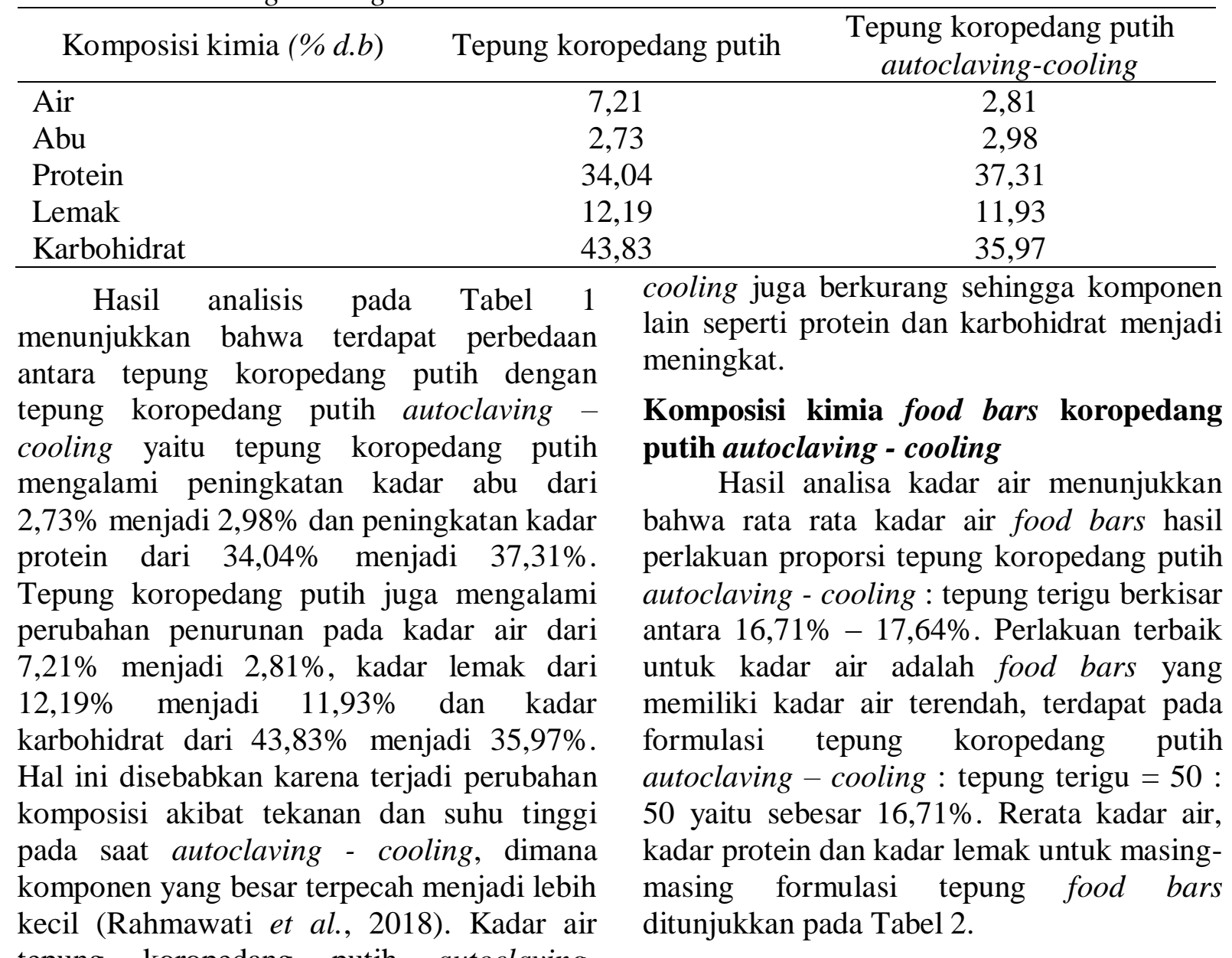


Tabel 2. Komposisi kimia food bars tepung koropedang putih autoclaving - cooling

\begin{tabular}{cccc}
\hline $\begin{array}{c}\text { Proporsi food bars (tepung } \\
\text { koropedang putih autoclaving } \\
\text { cooling : tepung terigu) }\end{array}$ & $\begin{array}{c}\text { Kadar Air } \\
(\% d b)\end{array}$ & $\begin{array}{c}\text { Kadar Protein } \\
(\% d b)\end{array}$ & $\begin{array}{c}\text { Kadar Lemak } \\
(\% d b)\end{array}$ \\
\hline $50: 50$ & $16,71 \pm 0,08^{\mathrm{d}}$ & $14,53 \pm 0,12^{\mathrm{e}}$ & $16,39 \pm 0,03^{\mathrm{b}}$ \\
$60: 40$ & $17,07 \pm 0,04^{\mathrm{c}}$ & $14,87 \pm 0,04^{\mathrm{d}}$ & $16,57 \pm 0,05^{\mathrm{a}}$ \\
$70: 30$ & $17,58 \pm 0,05^{\mathrm{ab}}$ & $15,12 \pm 0,05^{\mathrm{c}}$ & $16,64 \pm 0,02^{\mathrm{a}}$ \\
$80: 20$ & $17,64 \pm 0,03^{\mathrm{a}}$ & $15,41 \pm 0,03^{\mathrm{b}}$ & $16,62 \pm 0,03^{\mathrm{a}}$ \\
$90: 10$ & $17,49 \pm 0,02^{\mathrm{b}}$ & $15,59 \pm 0,02^{\mathrm{a}}$ & $16,63 \pm 0,02^{\mathrm{a}}$ \\
\hline
\end{tabular}

Keterangan: angka yang diikuti huruf yang berbeda antar kolom berbeda signifikan pada taraf nyata $5 \%$ menurut uji HSD Tukey

Tabel 2 menunjukkan bahwa nilai ratarata kadar air terbaik atau kadar air terendah adalah formulasi tepung koropedang putih autoclaving - cooling : tepung terigu $=50$ : 50. Hal ini disebabkan karena tepung koropedang puth autoclaving - cooling memiliki kemampuan mengikat air yang cukup baik, sehingga semakin sedikit proporsi tepung koropedang putih autoclaving - cooling maka semakin sedikit kadar airnya. Menurut Rahmawati et al. (2018) tepung koropedang putih yang diberi perlakuan autoclaving - cooling memiliki kemampuan pengikatan air (water holding capacity / WHC) ynang meningkat dari $232 \%$ menjadi $352 \%$. Sebagai perbandingan adalah kadar air food bars dari bahan tepung millet dan tepung kacang merah adalah sebesar 16,45\% (Ananditoet al., 2016).

Hasil analisa kadar protein menunjukkan bahwa rata rata kadar protein food bars hasil perlakuan formulasi tepung koropedang putih autoclaving - cooling : tepung terigu berkisar antara $14,53 \%$ $15,59 \%$. Perlakuan terbaik untuk kadar protein terdapat pada formulasi yang memiliki kadar protein tertinggi yaitu formulasi tepung koropedang putih autoclaving - cooling : tepung terigu $=90$ : 10 sebesar $15,59 \%$.

Semakin tinggi proporsi tepung koropedang putih autoclaving - cooling maka semakin tinggi nilai. Hal ini disebabkan karena tepung koropedang putih autoclaving - cooling mengandung protein cukup besar $(37,31 \%)$. Sebagai perbandingan adalah kadar protein food bars dari bahan tepung millet dan tepung kacang merah adalah sebesar 6,43\% (Ananditoet al., 2016). Food bars dari tepung koropedang putih autoclaving - cooling memiliki kadar protein lebih tinggi dikarenakan bahan baku koropedang putbih memiliki kadar protein cukup tinggi yaitu 32,13\% (Murdiati et al., 2015).

Hasil analisa kadar lemak menunjukkan bahwa rata rata kadar lemak food bars hasil perlakuan proporsi tepung koropedang putih autoclaving - cooling : tepung terigu berkisar antara 16,39\% $16,64 \%$. Perlakuan terbaik untuk kadar lemak terdapat pada formulasi dengan kadar lemak terendah yaitu formulasi tepung koropedang putih autoclaving - cooling : tepung terigu $=50: 50$ yaitu sebesar $16,39 \%$.

Semakin sedikit penambahan tepung koropedang putih autoclaving - cooling (50 : 50), kadar lemak food bars semakin kecil. Hal ini disebabkan karena tepung koropedang putih autoclaving - cooling mengandung lemak $(11,93 \%)$, sehingga menambah kadar lemak food bars. Hal ini diperkuat dengan hasil penelitian Rahmawati et al. (2018) ynang menunjukkan bahwa tepung koropedang putih yang diberi perlakuan autoclaving - cooling mengalami peningkatan kemampuan pengikatan lemak (oil holding capacity / OHC) yaitu dari 106\% menjadi $116 \%$, sehingga mampu mengikat lemak lebih banyak. Sebagai perbandingan kadar lemak foodbars dari bahan tepung millet dan tepung kacang merah adalah sebesar 9,2\% (Ananditoet al., 2016). 
Tabel 3. Komposisi kimia food bars tepung koropedang putih autoclaving - cooling

\begin{tabular}{ccc}
\hline $\begin{array}{c}\text { Proporsi food bars (tepung koropedang } \\
\text { putih autoclaving - cooling : tepung } \\
\text { terigu) }\end{array}$ & Kadar Abu $(\% \mathrm{db})$ & $\begin{array}{c}\text { Kadar Karbohidrat } \\
(\%)\end{array}$ \\
\hline $50: 50$ & $2,66 \pm 0,09^{\mathrm{b}}$ & $49,70 \pm 0,13^{\mathrm{a}}$ \\
$60: 40$ & $2,68 \pm 0,06^{\mathrm{b}}$ & $48,81 \pm 0,02^{\mathrm{b}}$ \\
$70: 30$ & $2,79 \pm 0,04^{\mathrm{ab}}$ & $47,87 \pm 0,05^{\mathrm{c}}$ \\
$80: 20$ & $2,82 \pm 0,01^{\mathrm{a}}$ & $47,52 \pm 0,03^{\mathrm{d}}$ \\
$90: 10$ & $2,85 \pm 0,01^{\mathrm{a}}$ & $47,45 \pm 0,01^{\mathrm{d}}$ \\
\hline
\end{tabular}

Keterangan: Angka yang diikuti huruf yang berbeda antar kolom berbeda signifikan pada taraf nyata 5\% menurut uji HSD Tukey

Hasil analisa kadar abu menunjukkan bahwa rata rata kadar abu food bars hasil perlakuan formulasi tepung koropedang putih autoclaving - cooling : tepung terigu berkisar antara $2,66 \%-2,85 \%$. Perlakuan terbaik untuk kadar abu terdapat pada formulasi yang memiliki kadar abu terendah, yaitu formulasi tepung koropedang putih autoclaving - cooling : tepung terigu $=50$ : 50 dengan kadar abu sebesar 2,66\%.

Semakin sedikit tepung koropedang putih autoclaving - cooling maka nilai kadar abu semakin rendah. Hal ini disebabkan karena tepung koropedang putih autoclaving - cooling memiliki kemampuan mengikat mineral. Hal ini ditunjukkan dalam penelitian Rahmawati et al. (2018) bahwa tepung koropedang putih yang diberi perlakuan autoclaving - cooling mengalami peningkatan kemampuan pengikatan kation mineral (Cation Exchange Capacity / CEC) dari $29 \mathrm{meq} / \mathrm{kg}$ menjadi $85 \mathrm{meq} / \mathrm{kg}$. Kadar abu dipengaruhi oleh kadar mineral dalam bahan. Sebagai pembanding, kadar abu food bars dari bahan tepung millet dan tepung kacang merah adalah sebesar $1,44 \%$ (Ananditoet al., 2016)..

Hasil analisa kadar karbohidrat (by difference) menunjukkan bahwa rata rata kadar karbohidrat food bars hasil perlakuan proporsi tepung koropedang putih autoclaving - cooling : tepung terigu berkisar antara 47,45\% - 49,70\%. Perlakuan terbaik untuk kadar karbohidrat terdapat pada formulasi dengan kadar karbohidrat terendah yaitu pada formulasi tepung koropedang putih autoclaving - cooling $:$ tepung terigu $=$ 90 : 10 sebesar 47,45\%. Rata-rata kadar karbohidrat untuk masing-masing formulasi tepung food bars. Kadar karbohidrat food bars dari bahan tepung millet dan tepung kacang merah adalah sebesar 24,7\% (Ananditoet al., 2016). Semakin banyak penambahan tepung koropedang putih autoclaving - cooling maka kadar karbohidrat semakin menurun. Hal ini disebabkan karena penambahan tepung koropedang putih autoclaving - cooling meningkatkan kadar protein food bars, sehingga kadar karbohidrat food bars semakin rendah sejalan dengan penambahan tepung koropedang putih autoclaving cooling.

\section{Daya patah dan tekstur}

Hasil analisa daya patah menunjukkan bahwa rata rata daya patah food bars hasil perlakuan formulasi tepung koropedang putih autoclaving - cooling : tepung terigu berkisar antara 1803,99 - 2429,09 gf. Perlakuan terbaik untuk daya patah terdapat pada formulasi dengan nilai daya patah tertinggi yaitu pada formulasi tepung koropedang putih autoclaving - cooling : tepung terigu $=50: 50$ sebesar 2429,09 gf. Tabel 3 menunjukkan rata-rata daya patah dan tekstur untuk masing-masing formulasi tepung food bars. 
Tabel 3. Daya patah dan tekstur food bars tepung koropedang putih autoclaving - cooling

\begin{tabular}{ccc}
\hline $\begin{array}{c}\text { Proporsi tepung koropedang putih } \\
\text { autoclaving - cooling }: \text { tepung terigu }\end{array}$ & Daya Patah $(\mathrm{gf})$ & Tekstur $(\mathrm{N})$ \\
\hline $50: 50$ & $2429,09 \pm 39,02^{\mathrm{a}}$ & $6,78 \pm 0,02^{\mathrm{a}}$ \\
$60: 40$ & $2269,30 \pm 13,83^{\mathrm{b}}$ & $6,43 \pm 0,02^{\mathrm{c}}$ \\
$70: 30$ & $1803,99 \pm 6,82^{\mathrm{e}}$ & $6,08 \pm 0,01^{\mathrm{e}}$ \\
$80: 20$ & $2106,42 \pm 7,59^{\mathrm{c}}$ & $6,30 \pm 0,02^{\mathrm{d}}$ \\
$90: 10$ & $1909,55 \pm 12,42^{\mathrm{d}}$ & $6,63 \pm 0,02^{\mathrm{b}}$ \\
\hline
\end{tabular}

Keterangan: angka yang diikuti huruf yang berbeda antar kolom berbeda signifikan pada taraf nyata 5\% menurut uji HSD Tukey

Tabel 3 menunjukkan bahwa semakin rendah proporsi penambahan tepung koropedang putih autoclaving - cooling, daya patah semakin tinggi. Hal ini disebabkan karena adanya pengaruh dari gluten yang ada pada tepung terigu. Gluten membantu menguatkan tekstur food bars sehingga tidak mudah patah. Semakin besar proporsi penambahan tepung terigu, semakin kuat tekstur food bars, sehingga nilai daya patahnya tinggi.

Hasil analisa tekstur menunjukkan bahwa rata rata tekstur food bars hasil perlakuan proporsi tepung koropedang putih autoclaving - cooling : tepung terigu berkisar antara $6,08-6,78 \mathrm{~N}$. Perlakuan terbaik untuk tekstur terdapat pada formulasi dengan nilai tekstur tertinggi yaitu pada formulasi tepung koropedang putih autoclaving cooling : tepung terigu $=50: 50$ sebesar 6,78 N. Semakin rendah proporsi penambahan tepung koropedang putih autoclaving cooling maka semakin tinggi nilai teksturnya. Hal ini disebabkan karena tepung terigu membantu memperkuat tekstur food bars melalui gluten yang ada dalam tepung terigu. Semakin banyak penambahan tepung terigu menyebabkan struktur food bars menjadi semakin kuat.

Hasil penelitian analisis tekstur pada food bars labu kuning dengan penambahan tepung kedelai dan tepung kacang hijau, menunjukkan nilai tekstur paling rendah sebesar 13,84 N. Hal ini disebabkan karena memiliki kandungan protein paling rendah dan diduga memiliki interaksi protein dan polisakarida yang paling sedikit sehingga memiliki tingkat kekerasan yang paling rendah (Fajri et al., 2013).

Hasil penelitian analisis daya patah food bars dari Tepung Komposit (Pedada,Talas dan Kedelai) menunjukkan tidak terdapat interaksi nyata $(\mathrm{p}>0,05)$ antara tepung talas dan tepung kedelai, namun terlihat meningkat dengan bertambahnya tepung talas. Hal ini disebabkan karena kandungan pati pada tepung talas. Fungsi dari pati adalah untuk menjaga kekompakan dan kestabilan food bars. Pati yang ditambahkan pada bahan pangan memiliki fungsi untuk membentuk tekstur dan kepadatan, sebagai pengikat air, serta memperbesar volume (Jariyah et al., 2017).

\section{Warna $(\mathbf{L}, \mathbf{a}, \mathbf{b})$}

Warna food bars diukur dengan menggunakan colour reader, parameter yang dibaca adalah $\mathrm{L}, \mathrm{a}, \mathrm{b}$. Nilai $\mathrm{L}$ dinyatakan sebagai tingkat kecerahan dengan nilai 0 untuk hitam (gelap) dan 100 untuk putih (terang), axis a menunjukkan intensitas merah (+) atau hijau (-), axis $b^{*}$ menyatakan intensitas kuning $(+)$ atau biru (-). Tabel 4 menunjukkan nilai warna $(\mathrm{L}, \mathrm{a}, \mathrm{b})$ food bars tepung koropedang putih autoclaving cooling. 
Tabel 4. Warna (L, a, b) food bars tepung koropedang putih autoclaving - cooling

\begin{tabular}{cccc}
\hline $\begin{array}{c}\text { Proporsi tepung koropedang putih } \\
\text { autoclaving - cooling : tepung terigu }\end{array}$ & Warna (L) & Warna (a) & Warna (b) \\
\hline $50: 50$ & $72,41 \pm 0,07^{\mathrm{b}}$ & $18,66 \pm 0,06^{\mathrm{d}}$ & $15,91 \pm 0,07^{\mathrm{b}}$ \\
$60: 40$ & $79,59 \pm 0,03^{\mathrm{a}}$ & $15,71 \pm 0,04^{\mathrm{e}}$ & $17,21 \pm 0,03^{\mathrm{a}}$ \\
$70: 30$ & $64,36 \pm 0,10^{\mathrm{d}}$ & $23,28 \pm 0,06^{\mathrm{b}}$ & $12,40 \pm 0,03^{\mathrm{d}}$ \\
$80: 20$ & $68,25 \pm 0,05^{\mathrm{c}}$ & $21,03 \pm 0,10^{\mathrm{c}}$ & $14,98 \pm 0,05^{\mathrm{c}}$ \\
$90: 10$ & $61,07 \pm 0,11^{\mathrm{e}}$ & $25,38 \pm 0,07^{\mathrm{a}}$ & $11,12 \pm 0,06^{\mathrm{e}}$ \\
\hline
\end{tabular}

Keterangan: angka yang diikuti huruf yang berbeda antar kolom berbeda signifikan pada taraf nyata 5\% menurut uji HSD Tukey

Hasil analisa warna (L) menunjukkan bahwa kecerahan atau $\mathrm{L}$ food bars hasil perlakuan proporsi tepung koropedang putih autoclaving - cooling : tepung terigu berkisar antara 61,07 - 79,59. Perlakuan terbaik untuk warna (L) terdapat pada formulasi tepung koropedang putih autoclaving cooling : tepung terigu $=60: 40$ yaitu sebesar 79,59\%. Nilai rata-rata warna (L) tertinggi adalah formulasi tepung koropedang putih autoclaving - cooling : tepung terigu $=60: 40$. Hal ini disebabkan karena tepung koropedang putih autoclaving - cooling memiliki warna dasar kuning dan tepung terigu memiliki warna dasar putih sehingga perpaduan keduanya pada proporsi 60 : 40 menyebabkan food bars terlihat lebih terang.

Tabel 4 menunjukkan warna (a) tertinggi terdapat pada proporsi $90: 10$. Hal ini disebabkan karena warna tepung koropedang putih autoclaving - cooling cenderung kuning kemerahan, sehingga semakin banyak proporsi tepung koropedang autoclaving - cooling (90:10) maka nilai warna (a) semakin tinggi. Warna (b) menunjukkan warna kuning. Tabel 4 menunjukkan bahwa warna (b) tertinggi terdapat pada proporsi $60: 40$. Hal ini disebabkan karena tepung koropedang putih autoclaving - cooling memiliki warna cenderung kuning kemerahan, sehingga proporsi 60 : 40 menyebabkan warnanya kuning.

\section{Uji organoleptik}

Rerata kesukaan panelis terhadap warna dari formulasi tepung koropedang putih autoclaving - cooling : tepung terigu berkisar antara 3,56 (netral) sampai 4,08 (suka). Berdasarkan hasil analisis ragam kesukaan warna menunjukkan bahwa proporsi tepung koropedang putih autoclaving - cooling dan tepung terigu memberikan pengaruh sangat nyata terhadap kesukaan warna food bars. Skor nilai yang digunakan untuk penilaian tingkat kesukaan adalah 5 (suka sekali), 4 (suka), 3 (netral), 2 (tidak suka) dan 1 (sangat tidak suka). Rerata kesukaan panelis terhadap warna disajikan pada Tabel 5.

Tabel 5. Organoleptik food bars tepung koropedang putih autoclaving - cooling

Proporsi tepung koropedang

putih autoclaving - cooling :

Warna

Rasa

Aroma

Tekstur tepung terigu

\begin{tabular}{lllll}
$50: 50$ & $3,56 \pm 0,39^{\mathrm{a}}$ & $3,63 \pm 0,38^{\mathrm{a}}$ & $3,92 \pm 0,38^{\mathrm{a}}$ & $3,83 \pm 0,13^{\mathrm{a}}$ \\
$60: 40$ & $4,02 \pm 0,42^{\mathrm{a}}$ & $3,88 \pm 0,56^{\mathrm{a}}$ & $3,83 \pm 0,25^{\mathrm{a}}$ & $3,83 \pm 0,20^{\mathrm{a}}$ \\
$70: 30$ & $3,71 \pm 0,07^{\mathrm{a}}$ & $3,75 \pm 0,22^{\mathrm{a}}$ & $3,67 \pm 0,22^{\mathrm{a}}$ & $3,65 \pm 0,10^{\mathrm{a}}$ \\
$80: 20$ & $3,92 \pm 0,13^{\mathrm{a}}$ & $4,02 \pm 0,14^{\mathrm{a}}$ & $3,75 \pm 0,17^{\mathrm{a}}$ & $3,90 \pm 0,14^{\mathrm{a}}$ \\
$90: 10$ & $4,08 \pm 0,36^{\mathrm{a}}$ & $3,92 \pm 0,32^{\mathrm{a}}$ & $3,69 \pm 0,31^{\mathrm{a}}$ & $3,63 \pm 0,17^{\mathrm{a}}$ \\
\hline
\end{tabular}

Keterangan: angka yang diikuti huruf yang berbeda antar kolom berbeda signifikan pada taraf nyata 5\% menurut uji HSD Tukey 
Tabel 5 menunjukkan bahwa rata-rata kesukaan warna food bars tertinggi terdapat pada formulasi tepung koropedang putih autoclaving - cooling $:$ tepung terigu $=90: 10$, sedangkan rata-rata kesukaan warna food bars terendah terdapat pada formulasi tepung koropedang putih autoclaving - cooling : tepung terigu $=50: 50$. Formulasi $90: 10$ lebih disukai karena menampilkan warna kuning yang baik. Hal ini disebabkan karna dasar tepung koropedang putih autoclaving cooling yang berwarna kuning sehingga mendominasi warna food bars.

Rerata kesukaan panelis terhadap rasa dari formulasi tepung koropedang putih autoclaving - cooling : tepung terigu berkisar antara 3,63 (netral) hingga 4,02 (suka). Berdasarkan hasil analisis ragam kesukaan rasa menunjukkan bahwa proporsi tepung koropedang putih autoclaving - cooling dan tepung terigu memberikan pengaruh nyata terhadap kesukaan rasa food bars. Rata-rata kesukaan rasa food bars tertinggi terdapat pada formulasi tepung koropedang putih autoclaving - cooling $:$ tepung terigu $=80: 20$, sedangkan rata-rata kesukaan warna food bars terendah terdapat pada formulasi tepung koropedang putih autoclaving - cooling : tepung terigu $=50: 50$. Formulasi $80: 20$ mendapatkan nilai kesukaan rasa tertinggi disebabkan karena tepung koropedang putih autoclaving - cooling menimbulkan rasa gurih yang pas sehingga rasa food bars menjadi lebih disukai.

Rerata kesukaan panelis terhadap aroma dari formulasi tepung koropedang putih autoclaving - cooling : tepung terigu berkisar antara 3,67 (netral) sampai dengan 3,92 (netral). Berdasarkan hasil analisis ragam kesukaan aroma menunjukkan bahwa proporsi tepung koropedang putih autoclaving cooling dan tepung terigu memberikan pengaruh nyata terhadap kesukaan rasa food bars. Tabel 5 menunjukkan bahwa rata-rata kesukaan aroma food bars tertinggi terdapat pada formulasi tepung koropedang putih autoclaving - cooling $:$ tepung terigu $=50: 50$, sedangkan rata-rata kesukaan aroma food bars terendah terdapat pada formulasi tepung koropedang putih autoclaving - cooling : tepung terigu $=70: 30$. Formulasi $50: 50$ memperoleh skor kesukaan aroma tertinggi disebabkan karena adanya kombinasi aroma tepung koropedang putih autoclaving cooling dan tepung terigu yang seimbang sehingga menciptakan aroma yang enak.

Rerata kesukaan panelis terhadap tekstur dari formulasi tepung koropedang putih autoclaving - cooling : tepung terigu berkisar antara 3,63 (netral) sampai dengan 3,9 (netral). Berdasarkan hasil analisis ragam kesukaan tekstur menunjukkan bahwa proporsi tepung koropedang putih autoclaving - cooling dan tepung terigu memberikan pengaruh nyata terhadap kesukaan tekstur food bars. Tabel 5 menunjukkan bahwa rata-rata kesukaan tekstur food bars tertinggi terdapat pada formulasi tepung koropedang putih autoclaving cooling : tepung terigu $=80: 20$, sedangkan rata-rata kesukaan aroma food bars terendah terdapat pada formulasi tepung koropedang putih autoclaving - cooling $:$ tepung terigu $=$ 90 : 10. Formulasi 80 : 20 mendapat nilai kesukaan tekstur tertinggi disebabkan karena tepung koropedang putih autoclaving - cooling memiliki kadar serat cukup tinggi sehingga dapat membentuk tekstur yang cukup kuat pada food bars.

\section{Perlakuan terbaik}

Analisa perlakuan terbaik dilakukan menggunakan metode indeks efektivitas berdasarkan hasil analisis parameter fisik, kimia dan organoleptik. Formulasi yang terpilih sebagai perlakuan terbaik adalah formulasi tepung koropedang putih autoclaving - cooling $:$ tepung terigu $=60: 40$ dengan karakteristik kadar karbohidrat $48,81 \%$, kadar protein $14,87 \%$, kadar lemak $16,57 \%$, kadar air 17,07\%, kadar abu 2,68\%, daya patah $2269,3 \mathrm{gf}$, tekstur $6,43 \mathrm{~N}$, warna $\mathrm{L}$ 79,59 , warna a 15,71, warna b 17,21, organoleptik warna 4,02 , organoleptik rasa 3,88 , organoleptik aroma 3,83 , organoleptik tekstur 3,83

\section{Kadar pati resisten}

Kadar pati resisten berbeda antara tepung koropedang putih, tepung koropedang autoclaving-cooling dan foodbars berbeda secara signifikan. Kadar pati resisten selengkapnya pada Tabel 6. 
Tabel6. Kadar pati resisten pada tepung koropedang putih, tepung koropedang putih autoclaving-cooling dan foodbars

\begin{tabular}{lc}
\hline Nama & Pati Resisten (\%) \\
\hline tepung koropedang puth & 23,17 \\
tepung koropedang putih autoclaving-cooling & 27,45 \\
Foodbars perlakuan terbaik (proporsi 60:40) & 11,38 \\
\hline Keterangan: angka yang diikuti huruf yang berbeda antar kolom berbeda signifikan pada taraf
\end{tabular}

Keterangan: angka yang diikuti huruf yang berbeda antar kolom berbeda signifikan pada taraf nyata 5\% menurut uji HSD Tukey

Kadar pati resisten tepung koropedang putih meningkat karena adanya perlakuan autoclaving - cooling. Menurut Sajilata et al, (2015), perlakuan autoclaving - cooling dapat meningkatkan kadar pati resisten melalui gelatinisasi dan retrogradasi pati. Hasil penelitian Rahmawati et al. (2018) menunjukkan bahwa karbohidrat kompleks koropedang putih yang diberi perlakuan autoclaving - cooling satu siklus kadar pati resistennya meningkat dari $14,12 \%$ menjadi $16,68 \%$. Kadar pati resisten setelah menjadi produk food bars menurun menjadi 11,38\%. Hal ini disebabkan karena penambahan bahan-bahan lain seperti lemak dan protein mengurangi kadar pati resisten dalam bahan.

\section{KESIMPULAN}

Formulasi penambahan tepung koropedang putih autoclaving-cooling yang tepat untuk menghasilkan food bars dengan sifat fisik, kimia dan organoleptik terbaik adalah pada perbandingan tepung koropedang putih autoclaving - cooling : tepung terigu $=60: 40$. Formulasi ini memiliki karakteristik kadar karbohidrat $48,81 \%$, kadar protein $14,87 \%$, kadar lemak $16,57 \%$, kadar air 17,07\%, kadar abu 2,68\%, daya patah 2269,3 gf, tekstur $6,43 \mathrm{~N}$, warna L 79,59, warna a 15,71, warna b 17,21, organoleptik warna 4,02 , organoleptik rasa 3,88 , organoleptik aroma 3,83 , organoleptik tekstur 3,83, dan kadar pati resisten 11,38\%.

\section{UCAPAN TERIMA KASIH}

Ungkapan terima kasih kami sampaikan kepada LPPM Universitas Tribhuwana Tunggadewi atas pendanaan penelitian melalui Hibah Unitri.

\section{DAFTAR PUSTAKA}

De Garmo. (2004). Prosedur analisa perlakuan terbaik untuk penelitian pertanian. Jakarta: Universitas Indonesia.

Engelen, A. (2018). Analisis kekerasan, kadar air, warna dan sifat sensori pada pembuatan keripik daun kelor. Journal of Agritech Science, 2(1), 10 - 15.

Englyst, H. N., Kingman, S. M., \& Cummings, J. H. (1992). Classification and measurement of nutritionally important starch fractions. European Journal of Clinical Nutrition. 46(1) 533-550.

Estiasih, T. (2006). Teknologi dan aplikasi polisakarida dalam pengolahan pangan, Fakultas Teknologi Pertanian, Universitas Brawijaya Malang.

Fajri, R., Basito, \& Muhammad, D. R. A. (2013). Karakteristik fisikokimia dan organoleptik food bars labu kuning (Cucurbita máxima) dengan penambahan tepung kedelai dan tepung kacang hijau sebagai alternatif produk pangan darurat. Jurnal Teknologi Hasil Pertanian, 6(2), 103 - 110.

Foster, K., Holt, S. H., \& Brand-Miller, J. C., (2002). International table of glycemic index and glycemic load values: 2002. American Journal of Clinical Nutrition. 76(1), 5-56.

Guillon, F., \& Champ, M. M. J. (2002). Carbohydrate fractions of legumes: uses in human nutrition and potential for health. British Journal of Nutrition. 88(3), S293-S306.

Haralampu, S. G., (2000). Resistant starch a review of the physical properties and biological impact of $\mathrm{RS}_{3}$. 
Carbohydrate Polymer, 41, 285 - 292.

Holland, B., Unwin, I. D., \& Buss, D. H. (1992). Fruit and nuts. First supplement to5th edition ofMcCance and Widdowson's the composition of foods. London, United Kingdom: Her Majesty's StationeryOffice.

Jariyah, Karti, B. S. E, \& Pertiwi, Y. A. (2017). Evaluasi sifat fisikokimia food bar dari tepung komposit (pedada, talas dan kedelai) sebagai alternatif pangan darurat. Jurnal Rekapangan, 11(1), 70 -75 .

Lawal, O. S., \& Adebowale, K. O. (2005). physicochemical characteritics and thermal properties of chemically modified jack bean (Canavalia ensiformis) starch. Carbohyndratbe Polynmer, 60(1), 331-341.

Niba, I. L. (2003). Effect of storage period and temperature on resistant starch and beta-glucan content in cornbread. Food Chemistry, 83(4), $493-498$.

Nugent, A. P. (2005). Health properties of resistant starch. British Nutrition Foundation, London.

Ochoa, L., Michel, J. J. P., \& Soto, J. O. (2014). Complex carbohydrates as a possible source of high energy toformulate functional feeds. Advanced Food Nutrition Res, 73(1), 259-288.

Rahmawati, A., Murdiati, A., Marsono, Y., \& Anggrahini, S. (2018). Changes of complex carbohydrates of white jack bean (Canavalia ensiformis) during autoclaving - cooling cycles. Current Research In Nutrition and Food Science, 6(2), 470-480.

Sajilata, M. G., Singhai, R. S., \& Kulkarni, P. R. (2005). Resistant starch $-a$ review. Food Engineering and Technology Dept., Institute of Chemical Technology, Mumbai, India.

Sheahan, C. M. (2013). Jack Bean (Canavalia ensiformis (L.) DC", http://plants.usda.gov/plantguide/pdf/p g_caen4.pdf,

Siddhuraju, P., \& Becker, K. (2001). Species/variety differences in biochemical composition and nutritional value of Indian tribal legumes of the genus Canavalia. Nahrung/Food 45(1), 224-233.

Siswanto, A., Sutedja, A. M., \& Marsono, Y. (2015). Karakteristik cookies dengan variasi terigu dan tepung pisang tanduk pregelatinisasi. Jurnal Teknologi Pangan dan Gizi Vol 14(1), 17-21.

Sridhar, K. R., \& Seena, S. (2006). Nutritional and antinutritional significance of four unconventional legumes of the genus canavalia - a comparative study. Food Chem. 99(1), 267-288.

Subagio, A. (2005). Studies on physicochemical, functional and nutritional properties of proteins rom indonesia non-oil beans for their development as food additives. Faculty of Agricultural Technology, University of Jember.

Topping, D. (2007). Cereal complex carbohydrates and their contribution tohuman health. Journal of Cereal Science. 46(1), 220 - 229. 